\title{
Abnormal development of the locus coeruleus in Ear2(Nr2f6)-deficient mice impairs the functionality of the forebrain clock and affects nociception
}

\author{
Marei Warnecke, ${ }^{1}$ Henrik Oster, ${ }^{1}$ Jean-Pierre Revelli, ${ }^{2}$ Gonzalo Alvarez-Bolado, ${ }^{1}$ \\ and Gregor Eichele ${ }^{1,3}$ \\ ${ }^{1}$ Max-Planck-Institut für Experimentelle Endokrinologie, 30625 Hannover, Germany; ${ }^{2}$ Lexicon Genetics Inc., \\ The Woodlands, Texas 77381-1160, USA
}

\begin{abstract}
The orphan nuclear receptor Ear2 (Nr2f6) is transiently expressed in the rostral part of the rhombic lip in which the locus coeruleus (LC) arises. LC development, regulated by a signaling cascade (Mash1 $\rightarrow$ Phox $2 \mathrm{~b} \rightarrow$ Phox2a), is disrupted in Ear2 ${ }^{-/-}$embryos as revealed by an approximately threefold reduction in the number of Phox $2 a$ - and Phox $2 b$-expressing LC progenitor cells. Mash1 expression in the rhombic lip, however, is unaffected, placing Ear2 in between Mash1 and Phox2a/b. Dopamine- $\beta$-hydroxylase and tyrosine hydroxylase staining demonstrate that $>70 \%$ of LC neurons are absent in the adult with agenesis affecting primarily the dorsal division of the LC. Normally, this division projects noradrenergic efferents to the cortex that appear to be diminished in $\mathrm{Ear2}^{-/-}$since the cortical concentration of noradrenaline is four times lower in these mice. The rostral region of the cortex is known to contain a circadian pacemaker regulating adaptability to light- and restricted food-driven entrainment. In situ hybridization establishes that the circadian expression pattern of the clock gene Period1 is abolished in the Ear2 ${ }^{-/-}$forebrain. Behavioral experiments reveal that Ear2 mutants have a delayed entrainment to shifted light-dark cycles and adapt less efficiently to daytime feeding schedules. We propose that neurons in the dorsal division of LC contribute to the regulation of the forebrain clock, at least in part, through targeted release of noradrenaline into the cortical area.
\end{abstract}

[Keywords: Circadian rhythm; Ear2; forebrain clock; locus coeruleus; nociception; nuclear orphan receptor]

Supplemental material is available at http://www.genesdev.org.

Received July 20, 2004; revised version accepted December 23, 2004.

Nuclear hormone receptors are transcription factors that regulate the expression of specific target genes, thereby orchestrating numerous developmental and physiological processes (Beato et al. 1995; Kastner et al. 1995; Mangelsdorf et al. 1995; Thummel 1995). This protein superfamily consists of receptors that bind to hormones and "orphan" receptors some of which bind to small molecules while others may not have ligands. Several orphan receptors control facets of central nervous system development. Nurrl is required for the formation of midbrain dopaminergic neurons (Zetterstrom et al. 1997), in $R O R \alpha /$ staggerer mutants the growth response of Purkinje cells to thyroid hormone is impaired (Hamilton et al. 1996; Dussault et al. 1998), and COUP-TFI mutant

${ }^{3}$ Corresponding author.

E-MAIL gregor.eichele@mpihan.mpg.de; FAX 49-511-5359-186. Article and publication are at http://www.genesdev.org/cgi/doi/10.1101/ gad.317905. mice lack layer IV of the cerebral cortex, resulting from a compromised differentiation of subplate neurons (Zhou et al. 1999).

The orphan receptors COUP-TFI, COUP-TFII, and Ear2 (also known as Nr2f6) define a subfamily with Ear2 being a distant cousin. Ear2 forms homodimers and heterodimers with COUP-TFI and COUP-TFII (Avram et al. 1999) or thyroid hormone receptor $\beta$ (Zhu et al. 2000), and dimers bind to enhancers present in a wide range of genes (Ladias et al. 1992; Chu and Zingg 1997; Zhang and Dufau 2000). Ear2 is strongly expressed in human fetal liver and in the mouse embryo (Miyajima et al. 1988; Jonk et al. 1994), but there are no data available about its in vivo function, which prompted us to create a loss-offunction mouse mutant. Ear2 ${ }^{-/-}$mice are born alive and are fertile but lack $\sim 70 \%$ of the LC (locus coeruleus). This pontine nucleus is located along the lateral margin of the fourth ventricle and is the main source of the neurotransmitter NA (noradrenaline/norepinephrine) in 
the mammalian brain. Other neurotransmitters have also been found in the LC. Nonetheless, the importance of NA is underscored by the finding that $\mathrm{Dbh}$ (dopamine$\beta$-hydroxylase) mutant mice, which are incapable of synthesizing NA (Thomas et al. 1995), exhibit a wide spectrum of behavioral and physiological defects (e.g., Thomas and Palmiter 1997a,b; Jasmin et al. 2002). The LC of rats contains $\sim 1700$ neurons (Swanson 1976), and cytoarchitectural criteria define a dorsal and a ventral division. The dorsal division is predominantly made of densely packed fusiform neurons, while the ventral division is characterized by less densely packed multipolar neurons (Swanson 1976). The topographical organization of the LC has been analyzed (Loughlin et al. 1986a,b). The spinal cord, for example, receives projections mostly from the ventral tip of the ventral division of the LC, while the various neocortical areas receive projection from the dorsal division with the exception of the frontal cortex that is innervated from the dorsal and ventral subdivisions (Waterhouse et al. 1983).

The web of projections emanating from the LC ensures that NA and other LC neurotransmitters reach nearly all regions of the CNS. Hence this nucleus influences a broad spectrum of physiological and behavioral processes such as arousal, alertness, sleep/wake cycle, nociception, anxiety, stress, cognition, memory, and attention (for review, see Singewald and Philippu 1998; Berridge and Waterhouse 2003). Deficits in LC function are associated with several neurological disorders such as Parkinson syndrome, attention deficit hyperactivity disorder, depression, and epilepsy (for review, see Berridge and Waterhouse 2003). Aston-Jones et al. (2001) have reported that the firing rate of LC neurons exhibits a circadian pattern, suggesting a participation of the LC in circadian timing systems. In addition to its neuronal connections with the central circadian clockwork of the SCN (suprachiasmatic nucleus of the hypothalamus), the LC sends efferents to various areas of the brain (Aston-Jones et al. 2001; Aston-Jones 2004), some of which house their own circadian pacemakers. For the forebrain region one of these pacemakers has been functionally characterized in a mouse mutant for Npas2, a paralog of the Clock gene expressed in this area but not in the SCN (Reick et al. 2001; Dudley et al. 2003).

LC progenitor cells are born in the rostral rhombic lip (e.g., Lin et al. 2001), migrate ventrally within the developing neural tube, and take residency near the fourth ventricle. Several molecular determinants of LC development have been discovered (for review, see Brunet and Pattyn 2002; Goridis and Rohrer 2002). Initially, bone morphogenetic proteins (Bmps) generated in the roof plate induce Mash1, encoding a basic helix-loop-helix transcription factor, in LC progenitors of the adjacent rhombic lip (Guo et al. 1999; Vogel-Hopker and Rohrer 2002). Subsequently, Mash1 activates the homeobox genes Phox $2 a$ and Phox $2 b$. Hence, in the absence of Mash1 (Hirsch et al. 1998), Phox2a (Morin et al. 1997), or Phox2b (Pattyn et al. 2000), the LC does not form. Phox2a and Phox $2 b$ also regulate the expression of Th (tyrosine hydroxylase) and Dbh, two key enzymes of NA biosynthesis.
In the present study we investigate the developmental cause of LC agenesis seen in Ear2 ${ }^{-/-}$mice with a focus on the position of Ear2 in the signaling cascade implicated in LC specification. Moreover, we begin to characterize the physiological and behavioral consequences of an impaired LC with emphasis on its postulated role in the circadian timing system.

\section{Results}

Generation of Ear2-deficient mice

The Ear2 gene was disrupted in embryonic stem cells using homologous recombination. The first two coding exons (DNA-binding domain) were replaced by an IRESLacZ/MC1neo cassette using the pKOS/EAR2-39 target vector (Fig. 1A; Lexicon Genetics). Targeted ES clones were identified by Southern blotting, and a mouse line with a disrupted Ear2 gene was established. Animals were genotyped either by Southern blotting (Fig. 1B) or by PCR (Fig. 1C). In a $129 \mathrm{SvEv}^{\mathrm{Brd}} \times \mathrm{C} 57 \mathrm{BL} / 6 \mathrm{~J}$ albino genetic background, mice were born in the expected Mendelian ratio. Northern blot analysis of adult tissue revealed a single $2.5-\mathrm{kb}$ Ear2 transcript in several organs with strongest expression in liver and kidney (Fig. 1D). This 2.5-kb transcript was absent in mutant tissue, indicating that the Ear2 mutant was a null mutation.

\section{A dramatic reduction of neurons in the $L C$ in Ear2-deficient mice}

In situ hybridization and $L a c Z$ staining revealed that Ear2 was initially expressed at embryonic day 8.5 (E8.5) in a domain encompassing the dorsal mesencephalon and adjacent hindbrain tissue (Fig. 2A). In addition, expression was seen in the hindbrain in two stripes that localized to prerhombomeres A and B (Fig. 2A). By E9 the hindbrain had partitioned into distinct rhombomeres and LacZ staining was present in the dorsalmost part of rhombomeres 3 and 5 as well as at the midbrain-hindbrain boundary and the most rostral domain of rhombomere 1 (Fig. 2B). In this rhombomere staining was strongest dorsally in the rhombic lip (Fig. 2C), a germinative epithelium located at the boundary of the neural tube and the roof plate. At E11.5 Ear2 expression in the CNS rapidly decreased and in newborn and adult expression was, with the sole exceptions of Purkinje neurons and the choroid plexi, not detectable in the brain (data not shown).

The metameric expression pattern of Ear2 in the developing rhombencephalon raises the possibility that Ear2 $^{-/-}$embryos could be defective in hindbrain segmentation. Histological analysis of the mutant hindbrain, ISH (in situ hybridization) of segmentally expressed genes (Krox20 [also referred to as Egr2], Hoxb1, and Hoxa1) and immunohistochemical staining of neurofilaments of cranial nerves and ganglia, did not indicate any abnormalities in the architecture of the Ear2 ${ }^{-/}$embryonic hindbrain (data not shown). We next investigated 
Figure 1. Targeted mutagenesis of Ear2 in mice. (A) Targeting strategy for the Ear2 gene. Exons 1 and 2 encode the DNA-binding domain, and exons 3 and 4 encode the putative ligand-binding domain. A part of exon 1 and all of exon 2 are replaced by a LacZ/Neo cassette. (B) Southern blots: wild-type $(16 \mathrm{~kb})$ and mutant $(6.8 \mathrm{~kb})$ alleles are revealed by HindIII digestion and hybridization with a 595-bp 5' external probe (see $A$ ). (C) PCR genotyping using primers producing a 532-bp (wild type) or a 478-bp (mutant) fragment. (D) Northern blot analysis of adult liver and kidney reveal a $2.5-\mathrm{kb}$ mRNA in wild-type tissue. $\mathrm{EF} 1 \alpha$ serves as a loading control.
A

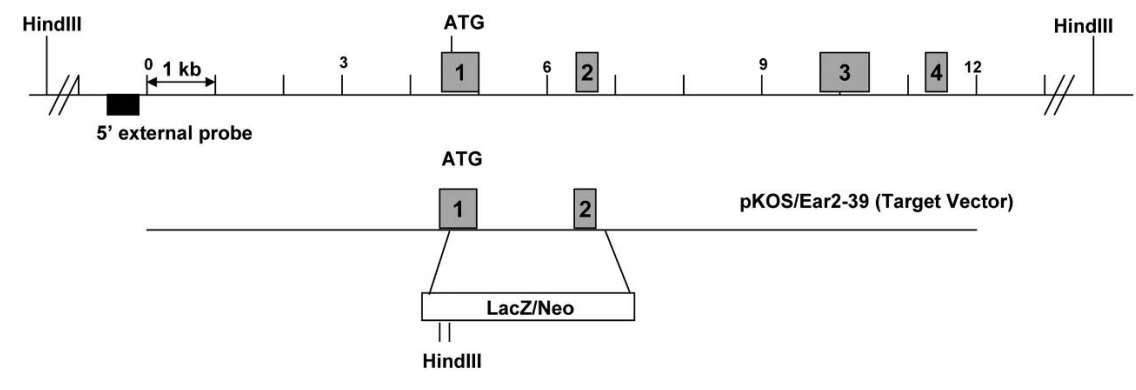

B

C

D

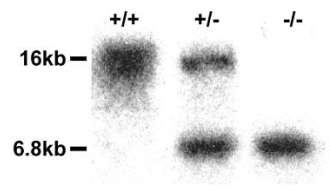

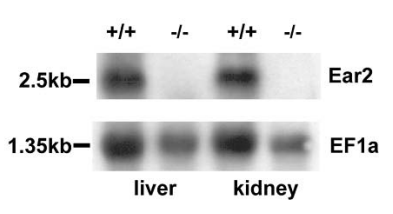

structures that derive from the rhombic lip at the level of rhombomere 1 . The precursors of the external granular layer of the cerebellum originate in the rhombic lip (for review, see Wingate 2001). Additionally, the rostral part of the rhombic lip gives rise to several neuronal populations in the pons (Wingate and Hatten 1999) and to the LC (Lin et al. 2001). If any of the corresponding precursor cell populations were affected in $\mathrm{Ear2}^{-/-}$mice, this should become apparent in the brain of adult mutant mice. A comparison of Nissl-stained serial sections through the brain of wild-type and $\mathrm{Ear2}^{-/-}$mice did not reveal any obvious morphologic defects in the cerebellum (Fig. 2D,D') consistent with the finding that expression of Math1, a determinant of external granular layer precursors (Ben-Arie et al. 1997), was not changed in E10.5 embryos (data not shown). We found, however, that cytoarchitecture and morphology of the LC were altered, and the number of neurons was dramatically reduced (Fig. 2E, $\mathrm{E}^{\prime}$ ).
The LC expresses Th and Dbh, which synthesize NA, the main neurotransmitter of the LC. Figure 3A compares the number of Th-positive cell bodies in serial coronal sections through a wild-type and an Ear2 ${ }^{-/-}$ brain. At all section levels a significant reduction of the number of LC cells was noted. To account for variability between different brains, the number of Th-positive neurons was determined in the LC of four wild-type and four mutant brains, and results were corrected for double counting of cells (Abercrombie 1946). This yielded $1284 \pm 24$ neurons for wild-type and $368 \pm 18$ neurons for Ear2 $^{-/-}$, corresponding to a $71 \%$ reduction in neuronal number in the mutant (Fig. 3B).

Neuronal agenesis was not uniform throughout the LC. Figure $3 \mathrm{C}-\mathrm{H}^{\prime}$ shows that agenesis affects mainly the dorsal division of the LC of Ear2 ${ }^{-/}$mice. A summary figure in which the boundaries of the LC of wild-type and mutant are stacked illustrates the dramatic size reduction and shape change of this nucleus in Ear2 $^{-/-}$mice
Figure 2. Expression of Ear2 in the embryo and brain anatomy of the adult Ear2 $^{-/-}$mouse. (A) Ear2 expression revealed by $L a c Z$ staining at E8.5 in prerhombomers $A$ and $B$ and in mesencephalon and adjoining hindbrain tissue. $(B)$ In a 9.25-d-old embryo LacZ staining is observed in rhombomeres 3 and 5 , at the midbrain-hindbrain junction, and the rostral part of rhombomere 1. (C) A transverse section through rhombomere 1 of a 9-d-old $L a c Z$-stained embryo shows strong $L a c Z$ staining in the rhombic lip. $\left(D-E^{\prime}\right)$ Nisslstained coronal sections through an adult wild-type $(D)$ and Ear2 $^{-/-}\left(D^{\prime}\right)$ brain. No morphological defects are seen in the mutant cerebellum, but partial agenesis of the LC (outlined with a black line in $E$ and $E^{\prime}$ ) is observed in Ear2 $2^{-/-}$mice. The mesencephalic nucleus of the fifth cranial nerve is an anatomical landmark. (LC) Locus coeruleus; (mes) mesencephalon; $(\mathrm{MH})$ midbrain-hindbrain boundary; $(\mathrm{MeV})$ mesencephalic nucleus of the fifth cranial nerve; (prA, prB) prerhombomeres $\mathrm{A}$ and $\mathrm{B}$; (r1, r3, r5) rhombomeres 1, 3, and 5; (rl) rhombic lip.
A
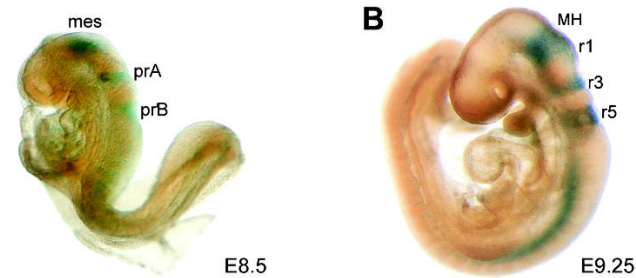

D $\quad$ D'
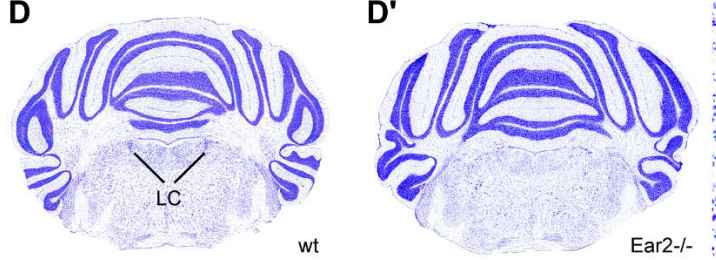

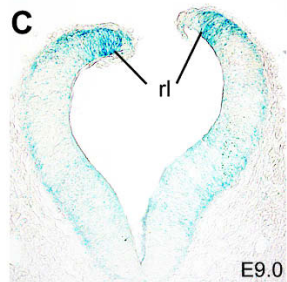

E9.0 
A
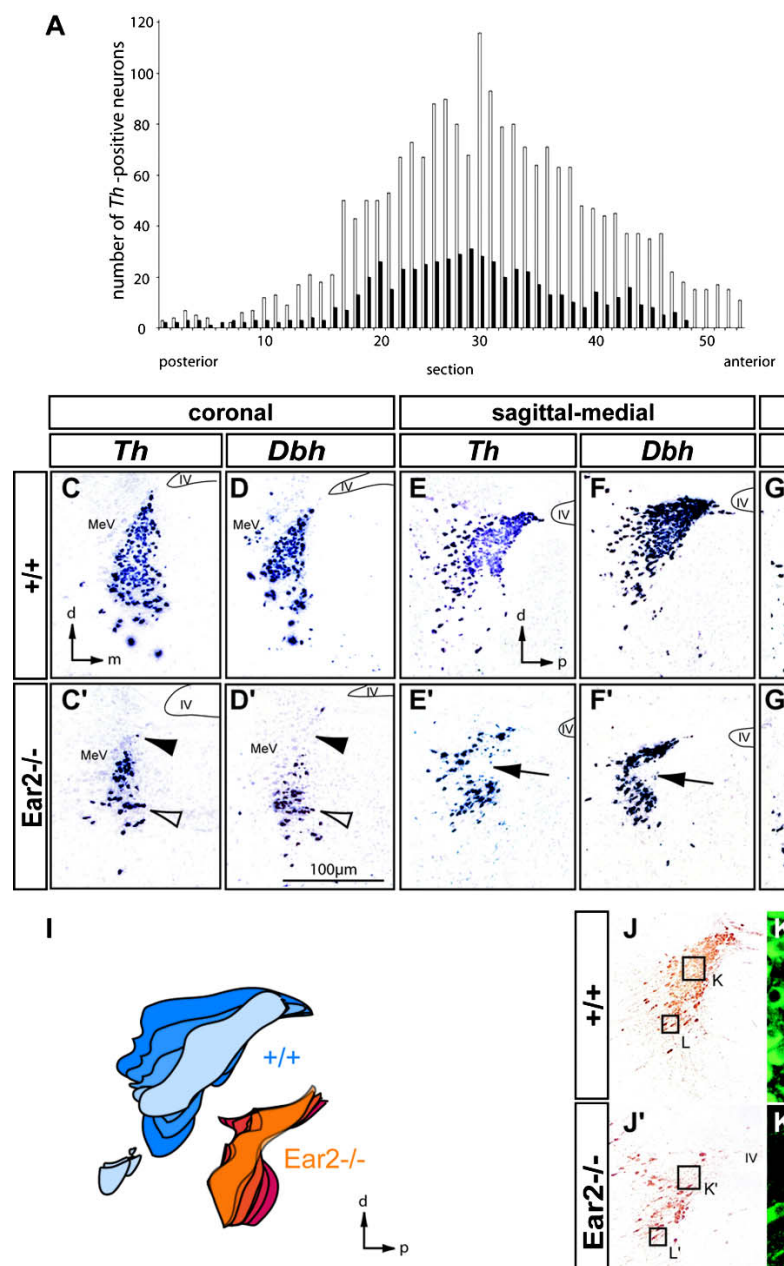

B

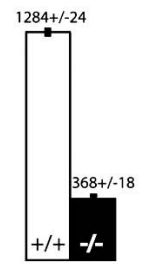

sagittal-lateral
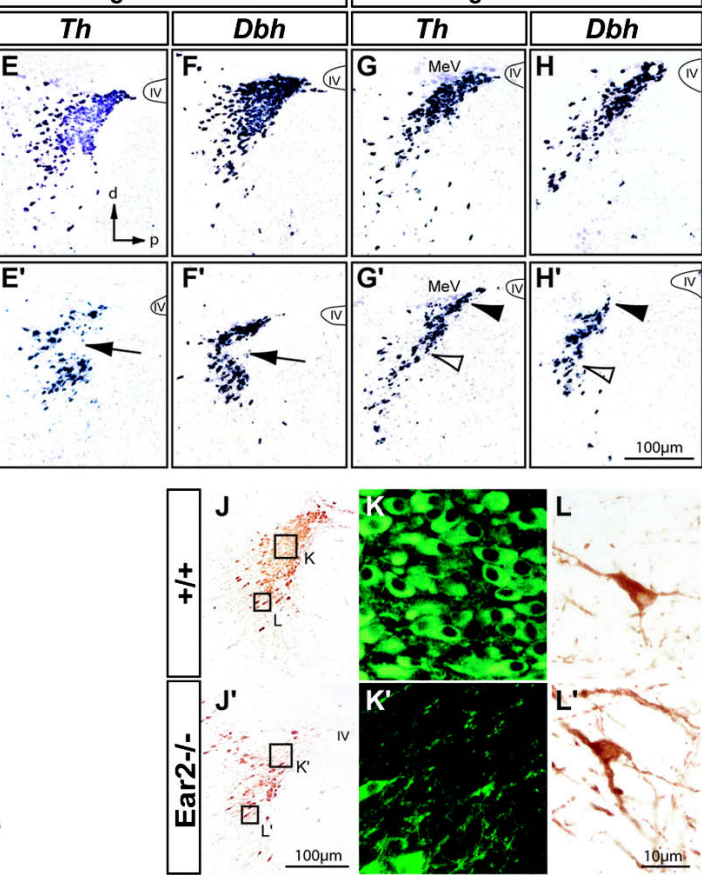

Figure 3. Anatomical changes of the LC in adult Ear2 $^{-/-}$mice documented by ISH $(A-$ $\left.H^{\prime}\right)$ and immunohistochemistry $\left(J-L^{\prime}\right) .(A)$ Tyrosine hydroxylase (Th)-positive cell bodies were counted in serial coronal sections through a wild-type (open bars) and Ear2 ${ }^{-/-}$ (black bars) LC. All section levels show a significant reduction of the number of LC neurons in $\mathrm{Ear2}^{-/-}$mice. (B) Cell counts of Thpositive LC neurons from four wild-type and mutant brains, corrected by the Abercrombie method. $\left(C-H^{\prime}\right)$ Comparison of the neuroanatomy of wild-type and Ear2-/- LC revealed by $T h$ and $D b h$ staining. The mesencephalic nucleus and fourth ventricle serve as anatomical landmarks. Note the reduction in neuronal numbers in the dorsal division (black arrowheads), central core (arrows), and ventral division (open arrowheads) in Ear2 mutant brains. (I) Boundaries of the LC of wild-type and mutant mice were stacked to illustrate size and shape differences. $\left(J-L^{\prime}\right)$ Differences in cytoarchitecture between wild-type and mutant LC. The boxes in overview $J$ and $J^{\prime}$ lie within the regions characterized by fusiform $\left(K, K^{\prime}\right)$ and multipolar $\left(L, L^{\prime}\right)$ neurons and are enlarged in $K-L^{\prime}$. Densely packed fusiform neurons characteristic for the dorsal division $(K)$ are absent in the LC of Ear2 $^{-/-}$mice $\left(K^{\prime}\right)$, while large multipolar neurons found in the ventral division $(L)$ are retained in the mutant $\left(L^{\prime}\right)$. (d) Dorsal; (m) medial; (MeV) mesencephalic nucleus; (p) posterior; (IV) fourth ventricle.
(Fig. 3I). The coronal sections in Figure 3 hybridized with either Th (Fig. 3C, $\mathrm{C}^{\prime}$ ) or $\mathrm{Dbh}$ (Fig. 3D,D') probes demonstrate that the number of LC cells located in a region extending between the mesencephalic nucleus of the trigeminal nerve and the fourth ventricle was dramatically reduced in the LC of Ear2 ${ }^{-/-}$mice (Fig. 3C', $\mathrm{D}^{\prime}$, black arrowhead). Furthermore, both marker genes revealed a significant reduction of cell numbers throughout the ventral division of the mutant LC. Sagittal sections confirmed these interpretations. Both markers illustrate that the cell population adjacent to the fourth ventricle is diminished in mutant LC (Fig. 3E-H', black arrowheads in $\left.\mathrm{G}^{\prime}, \mathrm{H}^{\prime}\right)$. Moreover, the ventral division of the LC shows fewer cells in Ear2 ${ }^{-/-}$mice (Fig. 3C-D', G-H', open arrowheads). However, the characteristic multipolar Th-positive neurons of the ventral LC are still present in Ear2 ${ }^{-/-}$mice (Fig. 3, cf. L and L'). Another strong difference between wild-type and mutant LC is a "gap" located in the ventral part of the dorsal division (arrows in Fig. $\left.3 E^{\prime}, F^{\prime}\right)$, which in the wild-type LC consists predominantly of densely packed fusiform Th-positive neurons that are aligned parallel to the anteroposterior axis (Fig. 3J,K). In the case of Ear2 ${ }^{-/-}$, the population of fusiform neurons was nearly absent (Fig. $\left.3 \mathrm{~J}^{\prime}, \mathrm{K}^{\prime}\right)$.
Phox2a (Morin et al. 1997), Phox2b (Pattyn et al. 2000), and Mash1 (Hirsch et al. 1998) mutant mice lack an LC and are also devoid of all other noradrenergic centers of the brain (A1, 2, 5, 7). A1, 2, 5, 7 groups are not altered in Ear2 $^{-/-}$brains neither during development nor in the adult (data not shown). Taken together, the hallmark of Ear2 $^{-/-}$mice is a $70 \%$ reduction in the overall cell number of the LC with this reduction occurring in specific regions of the LC but being most conspicuous in its dorsal division.

\section{Ear2 acts upstream of a developmental cascade that specifies the noradrenergic cell fate of LC neurons}

A signaling cascade involving Bmp, Mash1, Phox2a, and Phox $2 b$ specifies development of the LC (see above). To place Ear2 into the context of this pathway, expression of Mash1, Phox2a, and Phox2b was examined in wildtype and Ear2 ${ }^{-/}$embryos. Expression of Mash1 in the dorsal part of rhombomere 1 was not affected in Ear2 $^{-/-}$ embryos (arrowhead in Fig. 4A, $\mathrm{A}^{\prime}$ ). In wild-type embryos Phox $2 a$ was expressed in ventrally migrating LC precursor cells located in the most rostral portion of rhombo- 
mere 1 (arrowhead in Fig. 4B). Although Ear2 ${ }^{-/-}$embryos still express Phox2a, the size of the Phox2a-positive cell cluster is greatly reduced (arrowhead in Fig. 4B'). This finding indicates that the reduction in cell number of the LC is already seen at the progenitor stage. Expression of Phox $2 b$ initiates shortly after Phox $2 a$ and is observed in wild-type embryos in a subset of Phox2a-positive cells (arrowhead in Fig. 4C; Pattyn et al. 2000). In Ear2 ${ }^{-/-}$embryos this group of Phox $2 b$-expressing cells was not detectable (Fig. $4 \mathrm{C}^{\prime}$ ). The small number of LC progenitors and the transient expression of Ear2 make it difficult to determine whether such cells are even born, and if they are, whether they undergo cell death or acquire a new fate.

We next analyzed the expression of Phox $2 a$, Th, and Dbh at E14.5 (Phox2b is not expressed after E11.5) (Pattyn et al. 2000), a stage when all LC precursors have migrated to their final destination lateral of the fourth ventricle and approach a post-mitotic stage. The sagittal sections of Figure $4 \mathrm{D}$ and $\mathrm{D}^{\prime}$ illustrate a significant reduction of Phox2a-positive cells in the LC. Similar to the situation in adult brain, agenesis is mainly observed in the most dorsal division of the LC (arrow in Fig. 4D') and in the core region (arrowhead in Fig. $4 \mathrm{D}^{\prime}$ ). This interpretation was supported by an analysis of $D b h$ and Th expression (Fig. 4E-F'). Cell counting of Dbh-expressing cells showed that the wild-type LC contained a total of $789 \pm 34$ neurons, whereas the mutant LC contained $285 \pm 33$ cells, a $64 \%$ reduction.
Taken together, an analysis of the developmental expression profile of LC determination and differentiation genes indicates that Ear2 is required early in the development of the LC. Because Phox $2 a$ and Phox $2 b$ but not Mash1 expression is altered in Ear2 ${ }^{-/-}$embryos, the most likely level of Ear2 function in the LC specification cascade is in between Mash1 and Phox2a. It should be noted, however, that Ear2 is required for the formation of not all but of $\sim 70 \%$ of LC neurons, predominantly but not exclusively those present in a densely clustered population of fusiform neurons of the dorsal part of the adult LC. The reduction in LC cell number is apparent already at the progenitor stage and is not a result of cell death of post-mitotic neurons.

\section{Functional defects in the circadian behavior}

The involvement of the LC in the regulation of the sleep/ wake cycle, the circadian firing pattern of LC neurons and the neuronal circuits linking the SCN and LC (for review, see Aston-Jones 2004) prompted us to examine whether $\mathrm{Ear2}^{-/-}$mice had a defective circadian timing system. We focused on the forebrain clock (Reick et al. 2001) since the cortex is richly innervated by noradrenergic projections from the dorsal division of the LC (Loughlin et al. 1986a,b), which is severely reduced in Ear2 ${ }^{-/-}$mice.

Mice kept in DD (constant darkness) were sacrificed at 6-h intervals, and the expression of the clock genes Per1, Per2, Bmal1, and Npas2 was determined by ISH on coro-

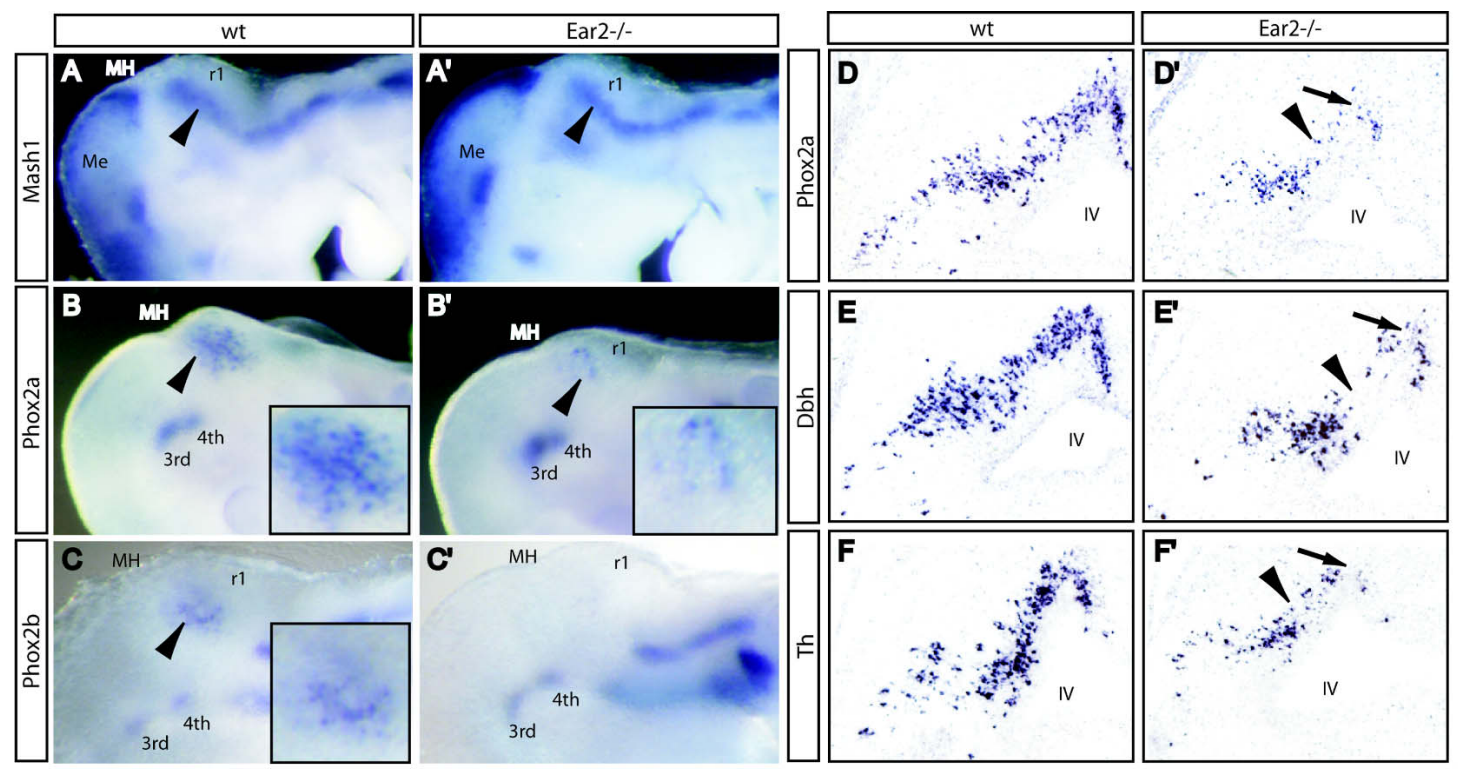

Figure 4. Expression of LC-determination and differentiation genes in the LC anlage at E9.5 and E14.5. $\left(A, A^{\prime}\right) M a s h 1$ expression in rhombomere 1 is unchanged (arrowhead) in mutant embryos. $\left(B, B^{\prime}\right)$ Phox $2 a$ is expressed in cells of the LC anlage (enlarged in inset) in wild type, but in mutant embryos the number of Phox2a-expressing cells is greatly diminished. $\left(C, C^{\prime}\right) P h o x 2 b$ is expressed in cells of the LC anlage of wild type (enlarged in inset), but Phox2b-positive cells are not detected in Ear2 ${ }^{-/-}$embryos. Note that the intensity of expression of $P h o x 2 a / b$ in the third and fourth cranial ganglion is similar for both genotypes, indicating that whole mounts were stained identically. $\left(D, D^{\prime}\right)$ Sagittal sections of the LC at E14.5 hybridized with Phox2a reveal agenesis in dorsal division (arrow) and core (arrowhead). (E-F') Identical results are observed with LC neuronal markers Dbh and Th. (r1) Rhombomere 1; (3rd and 4th) oculomotor and trigeminal ganglia; (IV) fourth ventricle. 
nal sections through the cortex. We found that the circadian oscillation of Per1 transcription was abolished and that of Per2 was dampened, but expression of Bmal1 and Npas2 was not significantly affected (Fig. 5A-D). It had previously been demonstrated that a deletion of Npas2, a paralog of Clock controlling the circadian oscillator in the forebrain, resulted in an altered adaptability to shifted LD (12 h dark/12 h light schedule) cycles and to daytime feeding schedules (Dudley et al. 2003). In the latter experiment, access to food is restricted to a time period of $3 \mathrm{~h}$ during the late morning hours, evoking anticipatory locomotor activity prior to food access (Stephan 2002) and altered clock gene expression in cortical and hippocampal regions (Wakamatsu et al. 2001). Ear2 mutants showed an impaired adaptability to a forward-shifted LD cycle (Fig. 5E). In addition, anticipatory locomotor activity of Ear2 ${ }^{-/}$ mice in an LD restricted feeding paradigm was significantly reduced compared to wild-type animals (Fig. $5 \mathrm{G}-\mathrm{I})$.

Since Per1 gene expression and two types of behavioral responses suggest that the forebrain clock is perturbed in
A
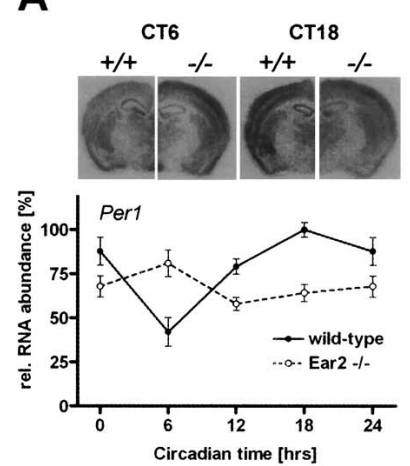

D
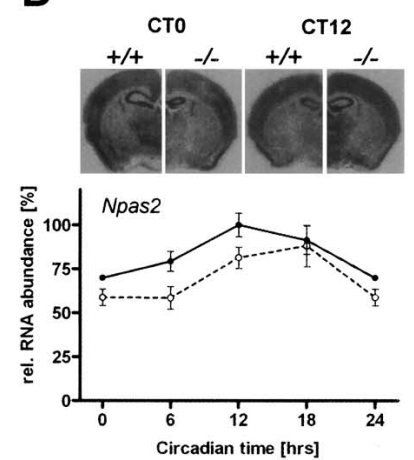

G

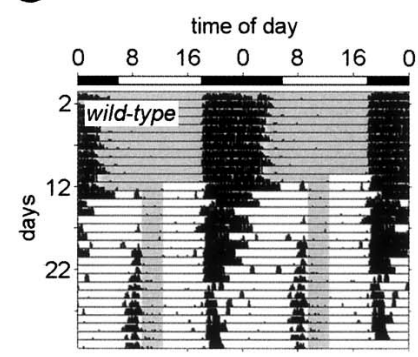

B
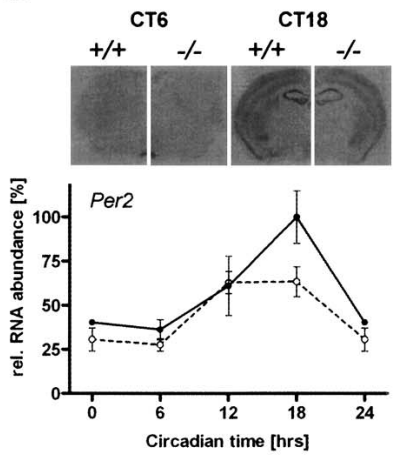

$\mathbf{E}$

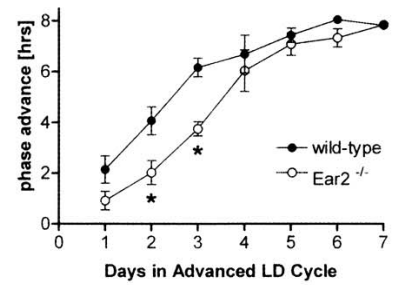

H

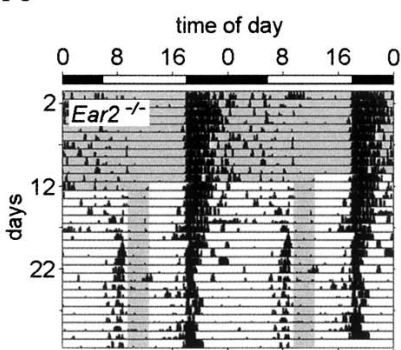

C
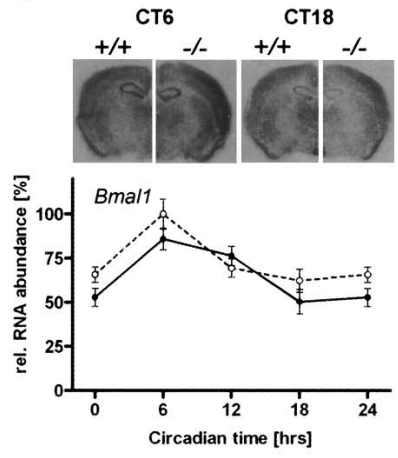

$\mathbf{F}$
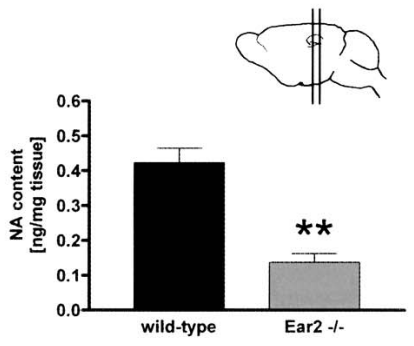

I

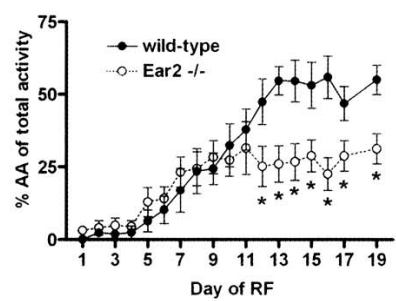

Figure 5. Impairment of the circadian forebrain oscillator in Ear2 ${ }^{-1-}$ mice. $(A-D)$ Circadian expression profiles of Per1 $(A)$, Per2 $(B)$, Bmal1 $(C)$, and Npas2 $(D)$ in the frontal cortex of wild-type and Ear2 ${ }^{-/-}$mice in DD. Upper panels show representative peak and trough autoradiographs for each genotype. Lower panels depict densitometric quantification of ISH hybridization signals on X-ray film $(n=3)$. $(E)$ Effect of an 8-h phase advance on activity onset in wild-type and Ear2 ${ }^{-/-}$mice. Shown is the mean daily advance in activity onset over $7 \mathrm{~d}$. Asterisks indicate significant differences in onset time for the genotypes on a particular day $(p<0.05$, Student's $t$-test, $n=6)$. $(F)$ NA levels in forebrain cortical slices of wild-type and Ear2 ${ }^{-/-}$mice measured in the middle of the subjective night (CT18, DD; $p=0.0096$, Student's $t$-test, $n=3)$. $(G-I)$ Behavioral adaptation of wild-type and Ear2 ${ }^{-/-}$mice to a 3-h restricted feeding schedule in LD. $(G, H)$ Representative double-plotted activity profiles of a wild-type $(G)$ and an Ear2 ${ }^{-/-}$mouse $(H)$. Black and white bars on top indicate light schedule; food access was restricted from 10 a.m. to 2 p.m. (I) Anticipatory activity (AA) normalized to total activity during 19 $\mathrm{d}$ of restricted feeding (asterisks indicate significant differences between wild-type and mutant animals; $p<0.05$; Student's $t$-test, $n=6)$. 
Ear2 $^{-/-}$mice, we examined whether these defects go together with altered levels of NA in this area. Animals were sacrificed at CT18, at which time Per gene expression was most different between the two genotypes, and NA levels were measured in frontal cortical slices. Mutant mice showed a three- to fourfold lower NA concentration (Fig. 5F), a reduction similar to that observed after chemical disruption of noradrenergic innervations (Cirelli and Tononi 2004). Our findings thus raise the possibility that the deficiencies of the forebrain clock are at least in part the result of reduced NA level in the cortex. Next we characterized the central oscillator of the SCN in Ear2 ${ }^{-/-}$mice. Mutant animals entrained normally to an LD cycle with a phasing of the wheel-running activity comparable to wild-type littermates (data not shown). When released into DD both wild-type and Ear2 $^{-/-}$animals showed a persistent endogenous rhythm with period lengths of $23.6 \pm 0.2$ and $23.7 \pm 0.4 \mathrm{~h}$, respectively (Fig. 6A). Consistent with this basic functionality of the SCN, rhythmic expression of clock genes such as Per1, Per2, and Bmal1 and of the clock output gene Prokineticin 2 (Prok2) in the SCN was not significantly different between wild-type and mutant mice (see Supplementary Fig. 1).

Although the SCN oscillator appeared normal in Ear2 mutants, closer inspection of activity recordings revealed changes in the accuracy of activity onset. In the case of wild-type mice kept in DD, the interval between activity onsets was stable with day-to-day variations of $\sim 13$ min, while in Ear2-deficient animals the variation was $\sim 26 \mathrm{~min}$ (Fig. 6A,B). This reduction of accuracy of activity onset was observed under various lighting conditions (Fig. 6B).

Exposing nocturnal animals to strong constant light puts the circadian pacemaker under stress (Aschoff 1979). We therefore monitored rhythm stability and period length of wild-type and Ear2 mutant mice in increasing intensities of constant light. Following Aschoff's rule (Aschoff 1955), both genotypes showed an increased period length proportional to the logarithm of the applied light intensity (Fig. 6C,D). In Ear2 mutants, however, the period length for a particular light condition was always shorter than in control animals (Fig. 6D). In addition, rhythm stability was severely affected in LL (constant light) with some mutants losing rhythmic activity profiles in light intensities even below 300 Lux (Fig. 6C,E), and five of six mice becoming arrhythmic at 400 Lux. In contrast, only one of six wild-type controls exhibited arrhythmic wheel-running activity under this condition (Fig. 6C,E).

In summary, Ear2 ${ }^{-/-}$mice show a spectrum of circadian defects. The major ones were a reduction in anticipatory locomotor activity in restricted feeding experiments, impaired re-entrainment to a shifted LD cycle, a loss of circadian Per1 expression, and dampening of Per2 expression in the frontal cortex (but not the SCN). These phenotypes go along with a marked reduction of cortical NA concentration. We also found that mutant mice dis-
Figure 6. The accuracy and stability of circadian wheel-running behavior is affected in Ear2 $^{-/-}$mice. (A) Representative locomotor activity records of wild-type and Ear2 $^{-/-}$mice (right panel) in DD. Activity is represented by vertical black bars. Red lines represent least-squares-fit regressions through the onsets of activity as calculated by the ClockLab software. $(B)$ Onset variability of wild-type and $\mathrm{Ear2}^{-/-}$ mice calculated as mean deviation of real onset from a least-squares-fit regression line over a period of 10 consecutive days in the given lighting conditions $\left(\left[{ }^{*}\right] p<0.05\right.$; $\left.\left[{ }^{\star \star}\right] p<0.01 ;{ }^{{ }^{\star \star \star}}\right] p<0.001$; Student's $t$ test, $n=12)$. (C) Representative locomotor activity records of wild-type and Ear2 ${ }^{-/-}$ mice in LD and LL of increasing intensity as indicated on the right side of the actograms. $(D)$ Internal period lengths $(\tau)$ of wild-type and Ear2 ${ }^{-/-}$mice in LL of different intensities. All $\tau$ values were significantly smaller in Ear2 $^{-/-}$animals for any tested LL condition $(p<0.05$; Student's $t$ test, $n=6)$. (E) Percentage of rhythmic animals in LL for wild-type and Ear2 ${ }^{-/-}$mice $(n=6)$. Animals were kept in each condition for at least $2 \mathrm{wk}$, and rhythmicity was determined by $\chi^{2}$ periodogram analysis.

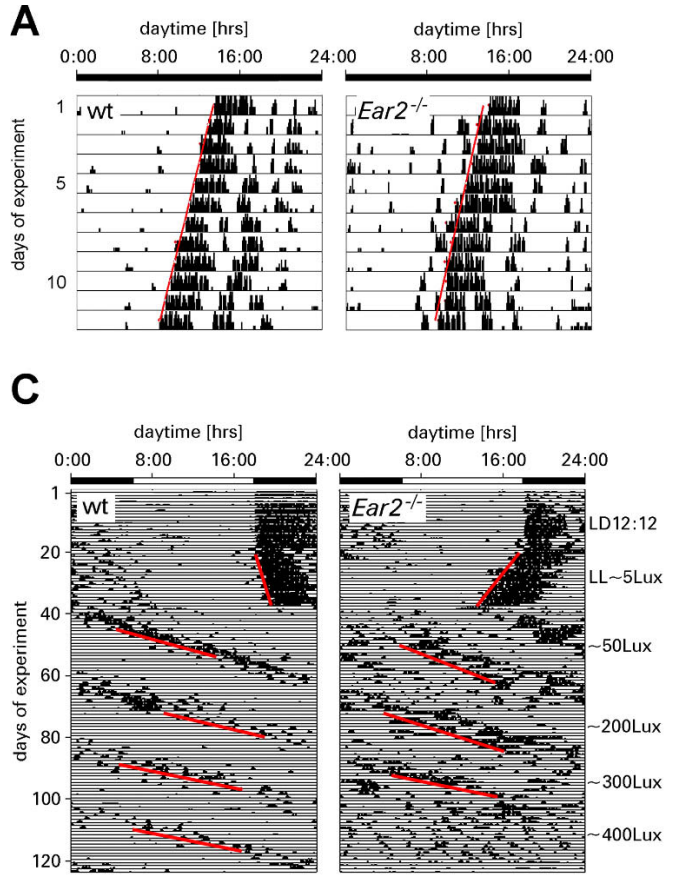

B

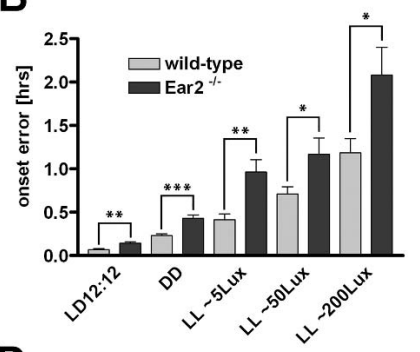

D

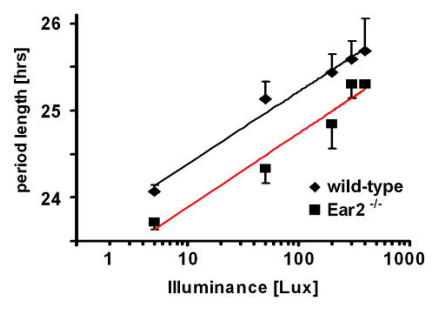

E

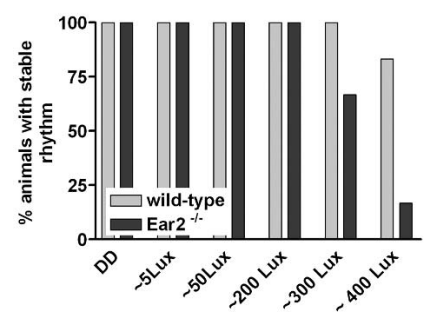


play reduced rhythm accuracy and become easily arrhythmic when exposed to higher levels of constant light.

\section{Increased nociception in Ear2 ${ }^{-/-}$mice}

The LC and the locus subcoeruleus (SC) belong to a descending pathway that regulates nociceptive neurons in the dorsal horn of the spinal cord (for review, see Willis et al. 2004). NA produced in the LC suppresses the activity of these nociceptive neurons (Mokha et al. 1985; Howe and Zieglgansberger 1987) and electrical stimulation of the LC/SC evokes antinociception that can be blocked by noradrenergic antagonists (Jones and Gebhart 1986, 1987). Since the majority of noradrenergic neurons projecting to the spinal cord originate either in the core or in the ventrocaudal part of the LC (Loughlin et al. 1986a,b and references therein) and both subpopulations of neurons are markedly reduced in the LC of Ear2 ${ }^{-/-}$mice, it is possible that the pain-modulatory effect of the descending inhibitory system is altered. To examine this, thermally evoked nociception of wild-type and Ear2 $^{-/-}$males was measured. Animals of $8 \mathrm{wk}$ of age and similar weight were placed onto a hot plate whose temperature was set at $53.5^{\circ} \mathrm{C}, 54^{\circ} \mathrm{C}$, or $54.5^{\circ} \mathrm{C}$. As a measure of pain sensitivity, the response latency from placing the animal onto the hot plate to lifting or licking a paw was recorded. Figure 7A shows that at all examined temperatures primary nociception of Ear2 $^{-/-}$animals was significantly increased. This difference in pain perception was further investigated by determining the secondary nociception of both genotypes. Ear2 ${ }^{-/-}$and wild-type animals were therefore placed onto a hot plate kept at $44^{\circ} \mathrm{C}$. The latency period was reduced by a factor of 3 in the mutant animal (Fig. 7B). Mice with artificial peripheral inflammation-the dorsal surface of both paws had been painted with allylisothiocyanate-showed a further decrease of the latency time by another factor of 2 (Fig. 7B). We next analyzed whether the concentration of NA was reduced in the spinal cord of mutant mice. In Ear2 ${ }^{-/-}$males the concentration of NA was reduced by $40 \%$ (Fig. 7C). Together, these results demonstrate that Ear2 $^{-I_{-}}$males exhibit a robust decrease in latency time to thermally evoked pain stimuli concomitant with a reduction of NA content of the spinal cord.

\section{Discussion}

A role of Ear2 in the specification of the $L C$

The LC radiates a network of axonal fibers to multiple regions of the CNS including cortex and spinal cord, thereby regulating a broad spectrum of behavioral and physiological functions (for review, see Singewald and Philippu 1998; Berridge and Waterhouse 2003). Understanding the development and function of the LC is thus of broad interest.

LC development is controlled by a signaling cascade (see above) that specifies LC progenitors. Our studies establish that the nuclear orphan receptor Ear2 plays a critical and early role in this process. Ear2 is transiently expressed in LC precursors at the time when they still reside in the rhombic lip. Mash1 is also expressed in the rhombic lip, and its pattern of expression is not affected in Ear2 $^{-/-}$embryos. In such embryos, however, the population of ventrally migrating LC precursors-characterized by Phox $2 a / b$ expression-is greatly diminished in size. The most parsimonious interpretation of these observations is that Ear2 functions in between Mash1 and Phox $2 a / 2 b$. It should be recalled that Phox $2 a / b$ mutants lack a LC (Morin et al. 1997; Pattyn et al. 2000). This apparently contradicts our suggestion of Ear2 being upstream of $P h o x 2 a / b$, but this is easily resolved by the finding that Ear2 is required for some but not all LC precursors to be formed. Thus our data suggest that Ear2 marks a branching point in the LC specification cascade, and make this gene an example of a LC subtype determinant. Analogous regional determinants have been identified in other systems such as the spinal cord and play key roles in the elaboration of neuronal identity and connectivity (Jessell 2000). As a regional determinant Ear2 would ultimately control the topographical organization of the LC (Loughlin et al. 1986a,b) and in this way, albeit indirectly, regulate the development of LC axonal projections. Agenesis of certain LC regions in Ear2 ${ }^{-/}$ would abolish the formation of a subset of LC afferents and efferents, and this could underlie the behavioral and physiological abnormalities that are observed in Ear2 $^{-/-}$mice. We have extensively examined morphology and gene expression in tissue that derive from Ear2-positive cells of rhombomeres 3 and 5 and found no abnormalities in mutants. This suggests that the phenotypes we describe here are chiefly due to the defective LC.
A

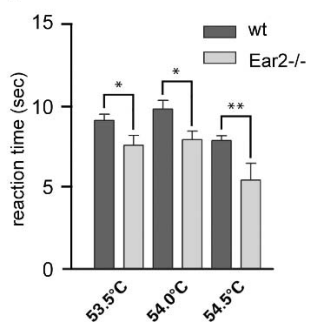

B

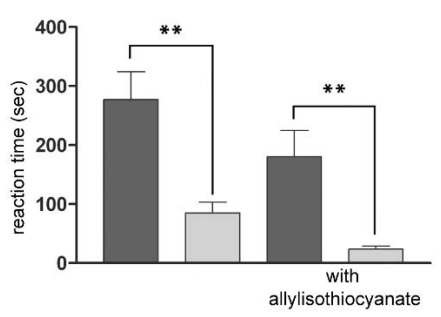

C

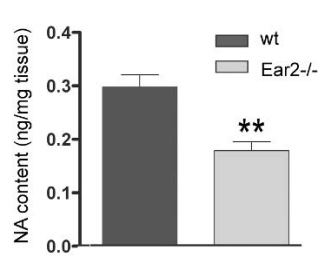

Figure 7. Nociception is increased in Ear2 mutant mice. (A) Response latency of wild-type and mutant animals in a hot plate test using three different temperatures. Male littermates $(n=10)$ were used for both genotypes. $(B)$ Response latency of wild-type and Ear2 ${ }^{-/-}$mice assessed at $44^{\circ} \mathrm{C}$ with and without prior application of allylisothiocyanate to the paws $(n=10)$. $(C)$ NA content in the spinal cord of wildtype and Ear2 ${ }^{-/-}$males $(n=6) .\left(\left[{ }^{\star}\right] p<0.05\right.$; $\left[{ }^{\star \star}\right] p<0.01$, Student's $t$-test). 
Defects in circadian behavior in Ear2 $2^{-/-}$mice implicate the LC in the circadian timing system

The principal deficiency in a circadian timing system of Ear2 mutant mice occurs in the pacemaker residing in the telencephalon. Three types of experiments support this interpretation. First, in mutant mice the circadian expression pattern in the cortex of the clock gene Per1 is abolished and that of Per2 is dampened. Second, kinetics of re-entrainment to a shifted LD cycle ("jet lag") is delayed, and third, the adaptability to restricted feeding is severely impaired. The above circadian phenotype could be linked to the partial agenesis of the LC in Ear2 ${ }^{-/-}$ mice. The cortex is richly innervated by projections from the dorsal division of this nucleus, a region that in Ear2 $^{-/-}$mice shows a dramatic reduction in neuronal number that would result in fewer LC efferents targeted to the cortex. Because of this, one expects a lower concentration of NA in mutant cortex, which is, indeed, the case as we show. Supportive evidence that NA and not another neurotransmitter of the LC is the clock-relevant cue comes from the finding that NA regulates Per1 expression in liver (Terazono et al. 2003) and pineal (von Gall et al. 2001) via second messenger pathways. One could envisage an analogous mechanism operating in the cortex, making NA a regulator of peripheral circadian clocks. LC cells express other transmitters in addition to NA, including arginine-vasopressin (AVP), galanin, and neuropeptide Y (NPY). Thus, it is possible that these agents also contribute to the circadian phenotype. It should be noted, however, that NPY and galanin as well as AVP may not be transported to LC terminals in the cortex, despite being located within LC somata that innervate these areas (Aston-Jones 2004).

The firing rate of the LC exhibits a circadian profile (Aston-Jones et al. 2001), raising the possibility that this nucleus contains its own molecular pacemaker. We did not, however, detect expression of any of the established clock genes (Per1, Per2, Clock, Bmal1, Cry1, and Cry2) (G. Eichele, unpubl.) in this area, which supports the argument that the LC itself does not harbor an endogenous oscillator. It is likely that the SCN drives the rhythmic firing pattern of the LC via the numerous direct and indirect LC-SCN projections (Legoratti-Sanchez et al. 1989; Aston-Jones et al. 2001; Krout et al. 2002; Vrang et al. 2003).

Given the neuronal connection between SCN, LC, and cortex, one can envisage the following scenario underlying the regulation of the pacemaker in the cortex. Cortical Per expression is regulated by NA, whose concentration fluctuates in a circadian manner in the cortex (Scheving et al. 1968). Such an oscillation could be the result of circadian release of NA regulated by the circadian firing pattern of the LC. Since the LC does not have its own clockwork, its rhythmicity would be imposed by the SCN making the LC a relay (Aston-Jones et al. 2001). In Ear2 mutant mice the SCN is apparently unaffected, but because the communication between LC and forebrain pacemaker is impaired, the observed behavioral deficiencies would emerge. It should be pointed out, however, that NA would be only one of several factors con- trolling the cortical clock, since rhythmic expression of some clock genes like Per2 and Bmal1 is maintained in the Ear2-deficient situation. Additionally, such mice may have altered circuits between the SCN and LC, and this may also contribute to the observed phenotype. It thus appears that in Ear2 mutant mice the input onto the cortical pacemaker is compromised. This distinguishes Ear2 from Npas2 mutants in which the oscillator itself is affected (Reick et al. 2001; Dudley et al. 2003). This line of reasoning is consistent with the fact that Npas2 but not Ear2 is expressed in adult cortex.

A neuroanatomical correlate for the observed reduction of accuracy and stability of the locomotor rhythm in Ear2-deficient mice remains to be identified. Several brain areas such as the dorsomedial nucleus of the hypothalamus (Chou et al. 2003), the paraventricular nucleus of the hypothalamus (Buijs et al. 2003), and the pineal gland (Armstrong 1989; Cassone 1992) modulate circadian behavior and rhythm stability. Most of those structures are innervated by the LC (e.g., Shirokawa and Nakamura 1987; Cunningham and Sawchenko 1988) and may hence singly or in combination contribute to the accuracy/stability phenotype.

\section{Increased nociception in Ear2 ${ }^{-/-}$mice}

The LC has a critical role in the modulation of pain reception with NA acting in an antinociceptive manner (Willis et al. 2004 and references therein). We experimentally assessed thermal nociception in Ear2 $^{-/-}$mice using standard hot plate tests and a setup involving artificial peripheral inflammation with mustard oil followed by a hot plate assay. In all paradigms statistically significant increases in nociception in mutant animals were observed, demonstrating that the antinociceptive system of the LC is impaired in Ear2 ${ }^{-/-}$animals. This can readily be understood in terms of a reduction in number of neurons in the ventral LC division known to project to the spinal cord (Loughlin et al. 1986a,b). Previous studies have demonstrated that bilateral LC lesions reduce the NA level of the spinal cord by $40 \%-70 \%$ (Nygren and Olson 1977; Karoum et al. 1980). In Ear2 ${ }^{-/-}$mice NA content was reduced by $40 \%$. The residual NA in mutants could derive from the remaining LC neurons and the $A 7$ group, which also sends noradrenergic fibers to the spinal cord (Westlund et al. 1982, 1983; for review, see Willis 2004) and which is intact in Ear2 ${ }^{-/-}$mice. $\mathrm{Dbh}^{-/-}$mice, unable to synthesize NA (Thomas et al. 1995), and Ear2 mutants show comparable alterations in thermal nociception (Jasmin et al. 2002).

A large number of physiological, pharmacological, and neuroanatomical studies implicate the LC in many physiologic and behavioral processes. The availability of a mouse mutant in which a major part of the LC is missing provides an opportunity to study the function of this important nucleus in a natural context. It will be interesting to explore whether Ear2 ${ }^{-/-}$mice display impairment of other functions attributed to the LC such as arousal, attention, alertness, anxiety, cognition, and memory. Additionally, it will be important to determine 
how the web of projections emanating from and received by the LC is altered in mutant mice.

\section{Materials and methods}

\section{Screening of ES cell colonies and generation of chimeric mice}

An Ear2 genomic clone from a $129 \mathrm{SvEv}^{\mathrm{Brd}}$ mouse genomic library (Lexicon Genetics) was isolated. The final targeting vector contained a thymidine kinase (TK) and an MC1 Neomycine resistance cassette (neo), which replaced the first two coding exons of the gene. The targeting vector was linearized and introduced into $129 \mathrm{SvEv}^{\mathrm{Brd}}$ embryonic stem (ES) cells by electroporation. G418-gancyclovir-resistant clones were screened for the occurrence of homologous recombination by Southern blotting. Clones with appropriately recombined Ear2 loci were injected into ES C57BL/6J albino blastocysts. Injected embryos were transferred into the uteri of pseudopregnant mothers. Chimeric mice were bred to C57BL/6J albino mice to generate F1 heterozygous animals. Ear2 heterozygotes were identified by Southern or PCR analysis and intercrossed to generate homozygotes. Genotypes were determined on tail or ES-cell lysates by Southern blot analysis or PCR. For Southern blotting isolated DNA was digested with HindIII, size separated in a $1 \%$ Trisborate EDTA buffer $(90 \mathrm{mM}$ Tris, $90 \mathrm{mM}$ borate, and $1 \mathrm{mM}$ EDTA at $\mathrm{pH}$ 8.4) agarose gel, and then capillary-transferred to an uncharged nylon membrane. The membranes were hybridized with an Ear2 5' external probe (Fig. 1A). PCR analysis using external and internal primers resulted in a 400-bp (Ear2 $\left.{ }^{-/}\right)$or a 550-bp amplicon (wild type). For all experiments described in this study we used mice in a $129 \mathrm{SvEv}^{\mathrm{Brd}} \mathrm{C} 57 \mathrm{BL} / 6 \mathrm{~J}$ hybrid background.

\section{Whole-mount and section ISH}

ISH on whole mounts was performed as described (Parr et al. 1993). Nonradioactive ISH on 20 - $\mu \mathrm{m}$ cryostat sections was carried out as previously described with a robotic platform and digoxygenin-labeled antisense riboprobes (Oldekamp et al. 2004). Templates for riboprobes were generated by RT-PCR from embryonic cDNA using specific forward and reverse primers. For template sequences see http://www.GenePaint.org (Visel et al. 2004). To count Th-positive neurons serially sectioned brains were used and results were corrected for double counting of cells (Abercrombie 1946). Radioactive in situ hybridization and quantification of expression strength on Kodak BioMax MS film was performed as described (Albrecht et al. 1998; Oster et al. 2002). The position of the SCN on sections was confirmed by bisbenzimide staining. Cortical expression strength was determined at Bregma levels $0.1-0.2 \mathrm{~mm}$ in a $0.5 \times 0.5-\mathrm{mm}$ square encompassing the barrel cortex.

\section{Immunohistochemistry}

Embryos were fixed in 4\% formaldehyde, embedded in paraffin, and sectioned at $10 \mu \mathrm{m}$. For antigen unmasking sections were incubated for $15 \mathrm{~min}$ in phosphate-buffered saline containing $0.1 \%$ Tween-20, boiled in a microwave oven for $5 \mathrm{~min}$ in $0.1 \mathrm{M}$ citrate buffer ( $\mathrm{pH}$ 6.0), and then rapidly cooled on ice. This heating/cooling cycle was repeated three times, each time using fresh citrate buffer. The primary antibody used was a monoclonal anti-Th antibody (AB152, Chemicon; dilution 1:250), subsequently detected with either HRP-labeled goat anti-rabbit antibody (Dianova, HRP 41553, dilution 1:100), or fluorescent goat anti-rabbit IgG (Alexa Fluor, A-11008; dilution 1:100).

\section{Measurement of NA}

NA contents were determined by ${ }^{125}$ I radioimmuno assay (NA Research RIA, LaborDiagnosticsNord). For cortical preparations wild-type and $\mathrm{Ear2}^{-/-}$animals were kept for $1 \mathrm{wk}$ in LD and released into DD on the day prior to the experiment. After brief anesthetization with Isoflurane, animals were decapitated, blood was collected in heparinized tubes, and brains were dissected and orientated using a rodent brain matrix (ASI Instruments). Two-millimeter-thick coronal slices were cut anterior of the optic chiasm, and cortical tissue was teased away using a lancet scalpel. For spinal cord preparations wild-type and Ear2 $^{-1-}$ animals were anesthetized and decapitated and the whole spinal cord was removed. Homogenization and the RIA were performed according to the manufacturer's protocol.

\section{Locomotor activity monitoring}

Mouse housing and handling were performed as described (Albrecht and Oster 2001). For LD-DD transitions lights were turned off at the end of the light phase and not turned on again the next morning. For the "jet lag" experiment the LD cycle was shifted forward for $8 \mathrm{~h}$ after a prolonged dark phase $(16 \mathrm{~h})$. Activity records were plotted in threshold format for 5-min bins. For activity counting and evaluation we used the ClockLab software package (Actimetrics). Onset stability was assessed by calculating the mean deviation of real activity onsets from the predicted onsets determined by a least-squares-fit regression line over two consecutive weeks. For LL experiments Ear2 ${ }^{-/-}$ and wild-type animals were exposed to increasing intensities of constant illumination using dimmable $12 \mathrm{~V}$ halogen lights above each cage. Light flux was measured with a Lux meter at the bottom of each cage. Rhythmicity and period length were determined by $\chi^{2}$ periodogram analysis and Fourier transformation using mice running in DD or LL for at least $1 \mathrm{wk}$. For daytime restricted feeding schedules (RF) animals were kept in LD and ad libitum food for at least $14 \mathrm{~d}$ prior to the experiment. On the first day of RF, food was removed from the cage at 13:00 (ZT6) and not returned before 10:00 (ZT3) the next morning. On the following days animals were allowed access to food from ZT3 to ZT6. Anticipatory activity was measured during $3 \mathrm{~h}$ prior to food access (ZT0 to ZT3) and compared to the overall activity of the same day.

\section{Hot plate test}

All experiments were carried out on a custom-made hot plate with males of the same age and weight. Primary nociception tests were performed as described $\left(\mathrm{O}^{\prime}\right.$ Callaghan and Holtzman 1975). Briefly, mice were placed on a hot plate kept at $53.5^{\circ} \mathrm{C}$, $54^{\circ} \mathrm{C}$, or $54.5^{\circ} \mathrm{C}$, and the time until animals started to lick or raise their hind paws was measured. The cutoff time was $15 \mathrm{sec}$. To assess second pain, mice were placed on a hot plate at $44^{\circ} \mathrm{C}$. The cutoff time was $400 \mathrm{sec}$.

In a second trial artificial peripheral inflammation was tested. Mustard oil was applied to the dorsal surface of both paws. After $3 \mathrm{~h}$ the animals were placed on a $44^{\circ} \mathrm{C}$ hot plate and latency time was determined. The cutoff time was $400 \mathrm{sec}$.

\section{Statistical analysis and counting}

Statistical analysis of all experiments was performed using GraphPad Prism software (GraphPad). Significant differences between groups were determined with Student's paired or unpaired $t$-test. Values were considered significantly different with $p<0.05\left(^{\star}\right), p<0.01\left(^{\star \star}\right)$, or $p<0.001\left(^{\star \star \star}\right)$. 


\section{Acknowledgments}

We thank Polina Spiess and Uwe Herzig for technical assistance. This work was supported in part by grants from the EU (QLG3-CT-2002-01829).

\section{References}

Abercrombie, M. 1946. Estimation of nuclear population from microtome sections. Anat. Rec. 94: 239-247.

Albrecht, U. and Oster, H. 2001. The circadian clock and behavior. Behav. Brain Res. 125: 89-91.

Albrecht, U., Lu, H.-C., Revelli, J.-P., Xu, X.-C., Lotan, R., and Eichele, G. 1998. Studying gene expression on tissue sections using in situ hybridisation. In Human genome methods (ed. K.W. Adolph), pp. 93-119. CRC Press, New York.

Armstrong, S.M. 1989. Melatonin and circadian control in mammals. Experientia 45: 932-938.

Aschoff, J. 1955. Daily periodicity in mice strains under constant environmental conditions. Pflugers Arch. 262: 51-59.

1979. Circadian rhythms: Influences of internal and external factors on the period measured in constant conditions. Z. Tierpsychol. 49: 225-249.

Aston-Jones, G. 2004. The Locus coeruleus, A5 and A7 noradrenergic cell groups. In The rat nervous system (ed. G. Paxinos), pp. 259-294. Elsevier Academic Press, San Diego.

Aston-Jones, G., Chen, S., Zhu, Y., and Oshinsky, M.L. 2001. A neural circuit for circadian regulation of arousal. Nat. Neurosci. 4: 732-738.

Avram, D., Ishmael, J.E., Nevrivy, D.J., Peterson, V.J., Lee, S.H., Dowell, P., and Leid, M. 1999. Heterodimeric interactions between chicken ovalbumin upstream promoter-transcription factor family members ARP1 and Ear2. J. Biol. Chem. 274: 14331-14336.

Beato, M., Herrlich, P., and Schütz, G. 1995. Steroid hormone receptors: Many actors in search of a plot. Cell 83: 851-857.

Ben-Arie, N., Bellen, H.J., Armstrong, D.L., McCall, A.E, Gordadze, P.R., Guo, Q., Matzuk, M.M., and Zoghbi, H.Y. 1997. Math1 is essential for genesis of cerebellar granule neurons. Nature 390: 169-172.

Berridge, C.W. and Waterhouse, B.D. 2003. The locus coeruleus-noradrenergic system: Modulation of behavioral state and state-dependent cognitive processes. Brain Res. Brain Res. Rev. 42: 33-84.

Brunet, J.F. and Pattyn, A. 2002. Phox2 genes-From patterning to connectivity. Curr. Opin. Genet. Dev. 12: 435-440.

Buijs, R.M., van Eden, C.G., Goncharuk, V.D., and Kalsbeek, A. 2003. The biological clock tunes the organs of the body: Timing by hormones and the autonomic nervous system. J. Endocrinol. 177: 17-26.

Cassone, V.M. 1992. The pineal gland influences rat circadian activity rhythms in constant light. J. Biol. Rhythms 7:27-40.

Chou, T.C., Scammell, T.E., Gooley, J.J., Gaus, S.E., Saper, C.B., and $\mathrm{Lu}, \mathrm{J}$. 2003. Critical role of dorsomedial hypothalamic nucleus in a wide range of behavioral circadian rhythms. $J$. Neurosci. 23: 10691-10702.

Chu, K. and Zingg, H.H. 1997. The nuclear orphan receptors COUP-TFII and Ear-2 act as silencers of the human oxytocin gene promoter. J. Mol. Endocrinol. 19: 163-172.

Cirelli, C. and Tononi, G. 2004. Locus ceruleus control of statedependent gene expression. J. Neurosci. 24: 5410-5419.

Cunningham Jr., E.T. and Sawchenko, P.E. 1988. Anatomical specificity of noradrenergic inputs to the paraventricular and supraoptic nuclei of the rat hypothalamus. J. Comp. Neurol. 274: 60-76.

Dudley, C.A., Erbel-Sieler, C., Estill, S.J., Reick, M., Franken, P.,
Pitts, S., and McKnight, S.L. 2003. Altered patterns of sleep and behavioral adaptability in NPAS2-deficient mice. Science 301: 379-383.

Dussault, I., Fawcett, D., Matthyssen, A., Bader, J.A., and Giguere, V. 1998. Orphan nuclear receptor ROR $\alpha$-deficient mice display the cerebellar defects of staggerer. Mech. Dev. 70: 147-153.

Goridis, C. and Rohrer, H. 2002. Specification of catecholaminergic and serotonergic neurons. Nat. Rev. Neurosci. 3: 531541.

Guo, S., Brush, J., Teraoka, H., Goddard, A., Wilson, S.W., Mullins, M.C., and Rosenthal, A. 1999. Development of noradrenergic neurons in the zebrafish hindbrain requires BMP, FGF8, and the homeodomain protein soulless/Phox2a. Neuron 24: 555-566.

Hamilton, B.A., Frankel, W.N., Kerrebrock, A.W., Hawkins, T.L., FitzHugh, W., Kusumi, K., Russell, L.B., Mueller, K.L., van Berkel, V., Birren, B.W., et al. 1996. Disruption of the nuclear hormone receptor $\mathrm{ROR} \alpha$ in staggerer mice. Nature 379: $736-739$.

Hirsch, M.R., Tiveron, M.C., Guillemot, F., Brunet, J.F., and Goridis, C. 1998. Control of noradrenergic differentiation and Phox2a expression by MASH1 in the central and peripheral nervous system. Development 125: 599-608.

Howe, J.R. and Zieglgansberger, W. 1987. Responses of rat dorsal horn neurons to natural stimulation and to iontophoretically applied norepinephrine. J. Comp. Neurol. 255: 1-17.

Jasmin, L., Tien, D., Weinshenker, D., Palmiter, R.D., Green, P.G., Janni, G., and Ohara, P.T. 2002. The NK1 receptor mediates both the hyperalgesia and the resistance to morphine in mice lacking noradrenaline. Proc. Natl. Acad. Sci. 99: 1029-1034.

Jessell, T.M. 2000. Neuronal specification in the spinal cord: Inductive signals and transcriptional codes. Nat. Rev. Genet. 1: 20-29.

Jones, S.L. and Gebhart, G.F. 1986. Quantitative characterization of ceruleospinal inhibition of nociceptive transmission in the rat. J. Neurophysiol. 56: 1397-1410.

- 1987. Spinal pathways mediating tonic, coeruleospinal, and raphe-spinal descending inhibition in the rat. J. Neurophysiol. 58: 138-159.

Jonk, L.J., de Jonge, M.E., Pals, C.E., Wissink, S., Vervaart, J.M., Schoorlemmer, J., and Kruijer, W. 1994. Cloning and expression during development of three murine members of the COUP family of nuclear orphan receptors. Mech. Dev. 47: 81-97.

Karoum, F., Commissiong, J.W., Neff, N.H., and Wyatt, R.J. 1980. Biochemical evidence for uncrossed and crossed locus coeruleus projections to the spinal cord. Brain Res. 196: 237-241.

Kastner, P., Mark, M., and Chambon, P. 1995. Nonsteroid nuclear receptors: What are genetic studies telling us about their role in real life? Cell 83: 859-869.

Krout, K.E., Kawano, J., Mettenleiter, T.C., and Loewy, A.D. 2002. CNS inputs to the suprachiasmatic nucleus of the rat. Neuroscience 110: 73-92.

Ladias, J.A., Hadzopoulou-Cladaras, M., Kardassis, D., Cardot, P., Cheng, J., Zannis, V., and Cladaras, C. 1992. Transcriptional regulation of human apolipoprotein genes ApoB, ApoCIII, and ApoAII by members of the steroid hormone receptor superfamily HNF-4, ARP-1, EAR-2, and EAR-3. $J$. Biol. Chem. 267: 15849-15860.

Legoratti-Sanchez, M.O., Guevara-Guzman, R., and SolanoFlores, L.P. 1989. Electrophysiological evidences of a bidirectional communication between the locus coeruleus and the suprachiasmatic nucleus. Brain Res. Bull. 23: 283-288.

Lin, J.C., Cai, L., and Cepko, C.L. 2001. The external granule 
layer of the developing chick cerebellum generates granule cells and cells of the isthmus and rostral hindbrain. J. Neurosci. 21: 159-168.

Loughlin, S.E., Foote, S.L., and Bloom, F.E. 1986a. Efferent projections of nucleus locus coeruleus: Topographic organization of cells of origin demonstrated by three-dimensional reconstruction. Neuroscience 18: 291-306.

Loughlin, S.E., Foote, S.L., and Grzanna, R. 1986b. Efferent projections of nucleus locus coeruleus: Morphologic subpopulations have different efferent targets. Neuroscience 18: 307-319.

Mangelsdorf, D.J., Thummel, C., Beato, M., Herrlich, P., Schütz, G., Umesono, K., Blumberg, B., Kastner, P., Mark, M., and Chambon, P. 1995. The nuclear receptor superfamily: The second decade. Cell 83: 835-839.

Miyajima, N., Kadowaki, Y., Fukushige, S., Shimizu, S., Semba, K., Yamanashi, Y., Matsubara, K., Toyoshima, K., and Yamamoto, T. 1988. Identification of two novel members of erbA superfamily by molecular cloning: The gene products of the two are highly related to each other. Nucleic Acids Res. 16: 11057-11074.

Mokha, S.S., McMillan, J.A., and Iggo, A. 1985. Descending control of spinal nociceptive transmission. Actions produced on spinal multireceptive neurones from the nuclei locus coeruleus (LC) and raphe magnus (NRM). Exp. Brain Res. 58: 213-226.

Morin, X., Cremer, H., Hirsch, M.R., Kapur, R.P., Goridis, C., and Brunet, J.F. 1997. Defects in sensory and autonomic ganglia and absence of locus coeruleus in mice deficient for the homeobox gene Phox2a. Neuron 18: 411-423.

Nygren, L.G. and Olson, L. 1977. A new major projection from locus coeruleus: The main source of noradrenergic nerve terminals in the ventral and dorsal columns of the spinal cord. Brain Res. 132: 85-93.

O'Callaghan, J.P. and Holtzman, S.G. 1975. Quantification of the analgesic activity of narcotic antagonists by a modified hot-plate procedure. J. Pharmacol. Exp. Ther. 192: 497-505.

Oldekamp, J., Kraemer, N., Alvarez-Bolado, G., and Skutella, T. 2004. bHLH gene expression in the Emx2-deficient dentate gyrus reveals defective granule cells and absence of migrating precursors. Cereb. Cortex 14: 1045-1058.

Oster, H., Yasui, A., van der Horst, G.T., and Albrecht, U. 2002. Disruption of mCry2 restores circadian rhythmicity in mPer2 mutant mice. Genes \& Dev. 16: 2633-2638.

Parr, B.A., Shea, M.J., Vassileva, G., and McMahon, A.P. 1993. Mouse Wnt genes exhibit discrete domains of expression in the early embryonic CNS and limb buds. Development 119: $247-261$.

Pattyn, A., Goridis, C., and Brunet, J.F. 2000. Specification of the central noradrenergic phenotype by the homeobox gene Phox2b. Mol. Cell. Neurosci. 15: 235-243.

Reick, M., Garcia, J.A., Dudley, C., and McKnight, S.L. 2001. NPAS2: An analog of clock operative in the mammalian forebrain. Science 293: 506-509.

Scheving, L.E., Harrison, W.H., Gordon, P., and Pauly, J.E. 1968. Daily fluctuation (circadian and ultradian) in biogenic amines of the rat brain. Am. J. Physiol. 214: 166-173.

Shirokawa, T. and Nakamura, S. 1987. Antidromic activation of rat dorsomedial hypothalamic neurons from locus coeruleus and median eminence. Brain Res. Bull. 18: 291-295.

Singewald, N. and Philippu, A. 1998. Release of neurotransmitters in the locus coeruleus. Prog. Neurobiol. 56: 237-267.

Stephan, F.K. 2002. The 'other' circadian system: Food as a Zeitgeber. J. Biol. Rhythms 17: 284-292.

Swanson, L.W. 1976. The locus coeruleus: A cytoarchitectonic, Golgi and immunohistochemical study in the albino rat. Brain Res. 110: 39-56.
Terazono, H., Mutoh, T., Yamaguchi, S., Kobayashi, M., Akiyama, M., Udo, R., Ohdo, S., Okamura, H., and Shibata, S. 2003. Adrenergic regulation of clock gene expression in mouse liver. Proc. Nat1. Acad. Sci. 100: 6795-6800.

Thomas, S.A. and Palmiter, R.D. 1997a. Thermoregulatory and metabolic phenotypes of mice lacking noradrenaline and adrenaline. Nature 387: 94-97.

- 1997b. Disruption of the dopamine $\beta$-hydroxylase gene in mice suggests roles for norepinephrine in motor function, learning, and memory. Behav. Neurosci. 111: 579-589.

Thomas, S.A., Matsumoto, A.M., and Palmiter, R.D. 1995. Noradrenaline is essential for mouse fetal development. Nature 374: 643-646.

Thummel, C.S. 1995. From embryogenesis to metamorphosis: The regulation and function of Drosophila nuclear receptor superfamily members. Cell 83: 871-877.

Visel, A., Thaller, C., and Eichele, G. 2004. GenePaint.org: An atlas of gene expression patterns in the mouse embryo. Nucleic Acids Res. 32: D552-D556.

Vogel-Hopker, A. and Rohrer, H. 2002. The specification of noradrenergic locus coeruleus (LC) neurones depends on bone morphogenetic proteins (BMPs). Development 129: 983-991.

von Gall, C., Schneider-Huther, I., Pfeffer, M., Dehghani, F., Korf, H.W., and Stehle, J.H. 2001. Clock gene protein mPER1 is rhythmically synthesized and under cAMP control in the mouse pineal organ. J. Neuroendocrinol. 13: 313-316.

Vrang, N., Mrosovsky, N., and Mikkelsen, J.D. 2003. Afferent projections to the hamster intergeniculate leaflet demonstrated by retrograde and anterograde tracing. Brain Res. Bull. 59: 267-288.

Wakamatsu, H., Yoshinobu, Y., Aida, R., Moriya, T., Akiyama, M., and Shibata, S. 2001. Restricted-feeding-induced anticipatory activity rhythm is associated with a phase-shift of the expression of mPer 1 and mPer 2 mRNA in the cerebral cortex and hippocampus but not in the suprachiasmatic nucleus of mice. Eur. J. Neurosci. 13: 1190-1196.

Waterhouse, B.D., Lin, C.S., Burne, R.A., and Woodward, D.J. 1983. The distribution of neocortical projection neurons in the locus coeruleus. J. Comp. Neurol. 217: 418-431.

Westlund, K.N., Bowker, R.M., Ziegler, M.G., and Coulter, J.D. 1982. Descending noradrenergic projections and their spinal terminations. Prog. Brain Res. 57: 219-238.

-1983. Noradrenergic projections to the spinal cord of the rat. Brain Res. 263: 15-31.

Willis, W.D., Westlund, K.N., and Carlton, S.M. 2004. Pain system. In The rat nervous system (ed. G. Paxinos), pp. 853-890. Elsevier Academic Press, San Diego.

Wingate, R.J. 2001. The rhombic lip and early cerebellar development. Curr. Opin. Neurobiol. 11: 82-88.

Wingate, R.J. and Hatten, M.E. 1999. The role of the rhombic lip in avian cerebellum development. Development 126: 4395-4404.

Zetterstrom, R.H., Solomin, L., Jansson, L., Hoffer, B.J., Olson, L., and Perlmann, T. 1997. Dopamine neuron agenesis in Nurr1-deficient mice. Science 276: 248-250.

Zhang, Y. and Dufau, M.L. 2000. Nuclear orphan receptors regulate transcription of the gene for the human luteinizing hormone receptor. J. Biol. Chem. 275: 2763-2770.

Zhou, C., Qiu, Y., Pereira, F.A., Crair, M.C., Tsai, S.Y., and Tsai, M.J. 1999. The nuclear orphan receptor COUP-TFI is required for differentiation of subplate neurons and guidance of thalamocortical axons. Neuron 24: 847-859.

Zhu, X.G., Park, K.S., Kaneshige, M., Bhat, M.K., Zhu, Q., Mariash, C.N., McPhie, P., and Cheng, S.Y. 2000. The orphan nuclear receptor Ear-2 is a negative coregulator for thyroid hormone nuclear receptor function. Mol. Cell. Biol. 20: 2604 2618. 


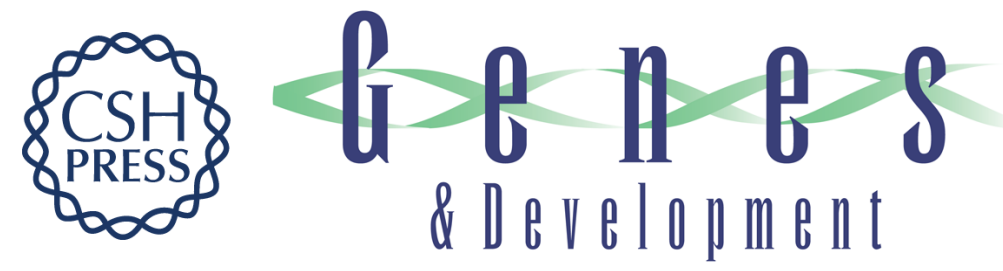

\section{Abnormal development of the locus coeruleus in Ear2(Nr2f6)-deficient mice impairs the functionality of the forebrain clock and affects nociception}

Marei Warnecke, Henrik Oster, Jean-Pierre Revelli, et al.

Genes Dev. 2005, 19:

Access the most recent version at doi:10.1101/gad.317905

Supplemental http://genesdev.cshlp.org/content/suppl/2005/02/11/19.5.614.DC1

Material

References This article cites 69 articles, 19 of which can be accessed free at: http://genesdev.cshlp.org/content/19/5/614.full.html\#ref-list-1

License

Email Alerting Receive free email alerts when new articles cite this article - sign up in the box at the top Service right corner of the article or click here.

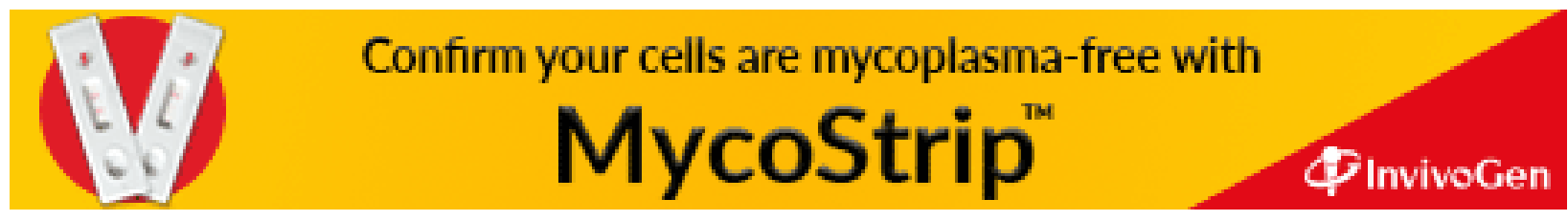

